\title{
Labour Market and Housing Unavailability: Implications for Regions Affected by Coal Mining
}

\author{
Eduard HROMADA ${ }^{1}$, Klára ČERMÁKOVÁ ${ }^{2}$ Tomáš KRULICKÝY , Veronika MACHOVÁ4, \\ Jakub HORÁK ${ }^{5}$, and Helena MITWALLYOVA6
}

\author{
Authors' affiliations and addresses: \\ ${ }^{1}$ Czech Technical University in Prague, Faculty \\ of Civil Engineering, Thakurova 7, 16629 Prague \\ 6, Czech Republic \\ e-mail: eduard.hromada@fsv.cvut.cz \\ ${ }^{2}$ Prague University of Economics and Business, \\ nam. W. Churchilla 1938/4, 13067 Prague 3, \\ Czech Republic \\ e-mail: klara.cermakova@vse.cz \\ ${ }^{3-5}$ Institute of Technology and Business in České \\ Budějovice, School of Expertness and Valuation, \\ Okružní 517/10, 37001 České Budějovice, Czech \\ Republic \\ e-mail: krulicky@mail.vstecb.cz \\ ${ }^{6}$ Prague University of Economics and Business, \\ nam. W. Churchilla 1938/4, 13067 Prague 3, \\ Czech Republic \\ e-mail: xmith900@vse.cz

\section{*Correspondence:} \\ Tomáš Krulický, Institute of Technology and \\ Business in České Budějovice, School of \\ Expertness and Valuation, Okružní 517/10, 370 \\ 01 České Budějovice, Czech Republic \\ tel.: +420 387842159 \\ e-mail: krulicky@mail.vstecb.cz \\ How to cite this article: \\ Hromada, E., Čermáková, K., Krulický, T., \\ Machová, V., Horák, J., and Mitwallyova, H. \\ (2021). Labour Market and Housing \\ Unavailability: Implications for Regions Affected \\ by Coal Mining. Acta Montanistica Slovaca, \\ Volume 26 (3), 404-414 \\ DOI: \\ https://doi.org/10.46544/AMS.v26i3.02
}

\begin{abstract}
Homeownership is becoming less affordable, even for middleincome households. This trend can also be observed in the Czech Republic, where the price to income ratio has been growing continuously during the last three decades in all major cities, Prague - the capital-over speeding this trend. This paper identifies key features of recent housing market development in the Czech Republic. We argue that the Czech case is relevant from an international perspective as there is an obvious lock-in effect enforced by either historical or current policy circumstances. Using unique data from EVAL software designed for mining data from sale and rental advertisements, we show some interesting trends in the housing market with implications to labour mobility and structural unemployment. The preference for property ownership in combination with the reduction of the coal industry causes a reduction in the mobility of the labour force and thus a reduction in the population's purchasing power, especially in localities with structural unemployment. The results show a significant dependence between real estate prices and labour mobility. These results are also important for regions affected by coal mining, as these are the less attractive regions in the Czech Republic. The article aims to offer a deeper insight into the relationship between housing ownership, cross-regional migration and structural unemployment and suggests policy solutions to improve housing availability.
\end{abstract}

\section{Keywords}

real estate prices, housing affordability, unemployment, labour market, household income, mining industry. 


\section{Introduction}

At the beginning of the COVID-19 pandemic, some experts assumed that real estate prices would fall. They expected an economic crisis similar to the one of 2008-2011 that would cause demand for real estate to cool (Shi, Sheng and Vochozka, 2017; Vochozka, Vrbka and Suler, 2020; Kliestik et al., 2018). However, according to current Eurostat data (2021), real estate prices are rising throughout the European Union (unlike the recession of 10 years ago), even during the lockdown periods. First, because during the Covid lockdown, people did not face any significant drop in their incomes. Second, because there is not necessarily an immediate reaction to the real estate market and an economic shock. Roulac (1996) found that the lag can vary from a number of weeks all the way to several years. The speed of real estate prices increase during and after the Covid pandemic has initiated frequent debates about housing affordability and its consequences.

Le Goix et al. (2021) identify key recent issues in housing affordability in urban areas: social distancing, gentrification and the accumulation of socio-economic inequalities in individual areas. The authors found that it is becoming increasingly difficult to access affordable housing in larger European cities. The study reports an increase in differences in housing affordability between and within cities. Affordability differentiation emphasizes the importance of mobility of the labour force and puts less flexible groups with limited mobility at a disadvantage, typically families with children. The price of real estate is also significantly affected by the time workers spend commuting to work. Kaderabkova et al. (2017) show how the affordability of housing decreases as the distance from the centre of Prague increases on data from the Czech Republic. Analysis has found that on average, every minute of commuting time closer to the city centre corresponds to an additional cost of approx. 1800 EURO for an average-sized apartment in the capital city of Prague.

Social aspects of increasing the unaffordability of housing are often stressed by experts. Krapf et al. (2020) analyze how the unavailability of housing and high real estate prices may influence the stability of partnership. The authors show that the risk of relationship breakdown is directly related to household income after deducting housing costs. The higher the household income after deducting housing costs, the lower the probability of the partnership breaking up. It was also found that property owners have more stable partnerships than tenants. It did not matter whether the property was jointly owned by both partners or only in the ownership of one partner.

The social aspect of housing un/affordability calls for adequate policy measures, and many experts concentrate on identifying efficient housing and social policy measures (Urban and Kajanova, 2020; Novak et al., 2016; Benczik, Juhasz and Mura, 2019). Andrews et al. (2011) examine individual housing policies in OECD countries. Based on a number of econometric analyses, these policies are examined in terms of achieving their goals and impacts on the state's economy. One of the main findings is that poorly designed policies can negatively affect the population's living standards, lead to higher volatility in property prices, and restrict the movement of people for job opportunities due to the unavailability of housing in the locality of interest. The study proposes some recommendations on how to make housing policies more effective to improve the housing market's functioning, improve macroeconomic stability, and make housing more accessible to a wider population. The issue of affordable housing in relation to the housing policy of individual states of the European Union is addressed by Kowalik et al. (2020). States with well-structured and developed social housing systems have been found to offer affordable housing to their citizens. At the same time, increasing government spending to boost housing demand is often counterproductive, as it tends to only increase local housing prices instead of improving housing affordability. The study, therefore, recommends that public financial resources are used to support the implementation of affordable housing projects, thus strengthening the supply side. The study also proposes a reform of real estate taxes. Proper tax targeting will support the local housing supply and reduce the negative effects of speculation on the residential market. The study also found that social and affordable housing is provided only for a very limited target group of socially disadvantaged people in many EU countries, which reduces the opportunities for the lower middle class to secure affordable housing. In the case of expanding support to a wider target group, more socially developed communities would be created, and social and spatial/residential segregation would be reduced.

Similarly, in various Czech regions, statistical data confirm that one of the factors that influence structural unemployment is the ratio of owner-occupied housing to rented housing (Jasova et al. 2016; Novak, 2017; Hrmo, Kristofiakova and Barnova, 2020). Obviously, housing ownership may be reflected in a higher rate of structural unemployment as property owners have less motivation and higher transaction costs to move to regions where there is adequate work for them. In this sense, subsidies to homebuyers or tax benefits increasing the ratio of homeowners to renters may be counterproductive. Overall, the Czech labour market is characterized by high rigidities resulting mainly from low labour mobility. Lux et al. (2012) argue that labour is mobile within regions, but mobility across regions is low and further decreasing. Traditionally the ratio of self-owned housing is high (near to $80 \%$ ), compared to, i.e. Germany, where nearly $50 \%$ of households live in rented housing. It can be assumed that the higher the share of households living in their own housing, the lower the labour mobility and higher the structural unemployment. This intuition corresponds to the Czech data. The total unemployment rate has been at low levels since 2014, but with a high share of structural unemployment. The demographic features of 
the Czech population also partly explain the high ratio of self-owned housing. The average age of the Czech population is increasing, which causes the share of households renting households to decrease. In fact, the young population is likely to rent instead of own.

The availability of housing will also be affected by the emphasis on buildings' total life cycle costs. Life cycle costing is a method of economic analysis directed at all costs related to constructing, operating, and maintaining a construction project over a defined period of time (Heralova, 2017). The optimization of the LCC of a project is very important and can bring significant cost savings in the long run (Macek, 2010). On the other hand, it requires higher input costs at the beginning of the investment. Unfortunately, this approach, as a side effect, worsens the availability of housing at present. The price of real estate also affects the way of reconstruction of older buildings (Vrbka et al., 2020) and the methods chosen to extend the life of the buildings (Krulicky et al., 2020).

Decreasing affordability of housing is also documented in many countries outside Europe. Leung et al. (2020) analyzed residential property prices in Hong Kong and came to similar conclusions. Hong Kong residential property prices are considered unaffordable, causing almost half of the population to live in either rental apartments or subsidized properties. The authors focus on the relationship between the housing market and basic macroeconomic parameters. It turns out that GDP is growing, the population is growing, longevity is increasing, but real wages and household incomes are lagging behind.

Similar conclusions were obtained by Kaderabkova et al. (2019), documenting that homeownership is becoming less affordable even for middle-income households. Kaderabkova examines wage inflation in different regions in relation to labour productivity which falls behind and concludes that the trend of wage inflation might further increase rents and real estate prices, making own housing further less affordable. Such a vicious circle might be interrupted by an increase in labour productivity rather than expansionary fiscal policies flourishing in the Czech economy during the Covid period. Novotná et al. (2021) pointed out that the main way to increase labour productivity in the Czech Republic is by investing in new technologies and innovations. These investments can be classified as intensive sources of growth (Volek and Novotná, 2015; Gavurova et al., 2021a; Gavurova et al. 2021b) leads to increase wages.

Trends prevailing in the real estate market and housing affordability in the Czech Republic are in some aspects similar to many other countries. However, our motivation in selecting the Czech case for our analysis was that we believe that the Czech case is relevant from an international perspective. There is an obvious lock-in effect enforced by either historical or by current policy circumstances. We focus on showing some interesting features and trends in the housing market with implications for labour mobility and structural unemployment. We will be seeking a relationship between real estate prices and labour mobility and aim to formulate policy recommendations that might prevent the worsening of housing unaffordability with its social consequences.

\section{Data and methodology}

The EVAL software application is used for data collection and analysis. The EVAL software systematically collects, analyses and evaluates real estate price offers published in real estate advertising on the Internet in the Czech Republic. This application was created and further expanded by one of the authors of this article.

Information is collected regularly by an automated mechanism over a period of one month, continuously since 2007. The EVAL software is structured into several sub-modules that work together:

- Module for collecting internet links.

- Module for downloading full texts of advertisements and exporting data.

- Data filtering module.

- Data evaluation module.

\section{A/ Module for collecting internet links:}

This part of the software tool systematically browses the real estate internet server and records current internet links to real estate sales or rental offers in the database. For this module to work, it was necessary to decipher the method of storing data on the real estate server. This module inserts more than 50,000 records of links to the full texts of individual advertisements into the EVAL software database each month.

\section{B/ Module for downloading full texts of advertisements and exporting data:}

The purpose of this part of the EVAL software tool is to automatically download the full text of the advertisement in a mechanical way and export data from the texts of the recorded advertisements, which will enable further statistical evaluation of the development of the real estate market. For each examined real estate category, its own data structure was defined, which is exported/obtained from the texts of recorded advertisements. 


\section{C/ Data filtering module:}

The database files are then subjected to data reliability analysis. Each recorded price offer is assessed in terms of objectivity and accuracy of the presented information, the completeness of the presented information is assessed, etc. In case of discrepancies, the assessed offer is excluded from further statistical processing. For selected parameters characterizing real estate, the author of the software defined a credible price or another value interval (with sufficient reserve) in which real estate transactions normally take place and real estate exists on the market. If the advertisement contains price or other value information outside this plausible band, this advertisement is excluded from further statistical processing.

\section{D/ Data evaluation module:}

This part of the software tool creates source data for the creation of statistical reports describing the development of the real estate market according to user requirements. The time development and dependencies between many monitored real estate parameters are examined. These statistical reports can be used to analyze the development of the real estate market, evaluate regional disparities in housing affordability, and forecast the development of real estate prices.

\section{Results}

Identifying a bubble in the real estate market is like reading from a crystal ball. Roulac (1996) identifies two principal sources of the property market cycle - financial excess and economic downturn, which reduces demand for space and rent levels. In the Czech Republic, the Covid economic downturn has been mitigated by a massive fiscal policy shelter. It also may be argued that the economic downturn has been quite short-lived so that it had no impact on property prices (not so for rents). A warning may come from an excess financial source. We have discussed some forces that comprise the Czech property market - increased savings, peaking volume of new mortgage contracts, loose monetary policy. The current sentiment of economic subjects on the demand and supply side of the Czech property market encourages positive expectations regarding property prices (realized sale prices currently exceed offer prices). This sentiment indicates property prices to grow - until investors reconsider their optimistic expectations.

The following graphs show the price development of flats offered for sale in the period from 2018 to June 2021, broken down by individual regions and cities. The results include both older flats and new buildings. It was found that especially after the onset of the COVID-19 pandemic, real estate prices have been rising across all regions and large cities in the Czech Republic.

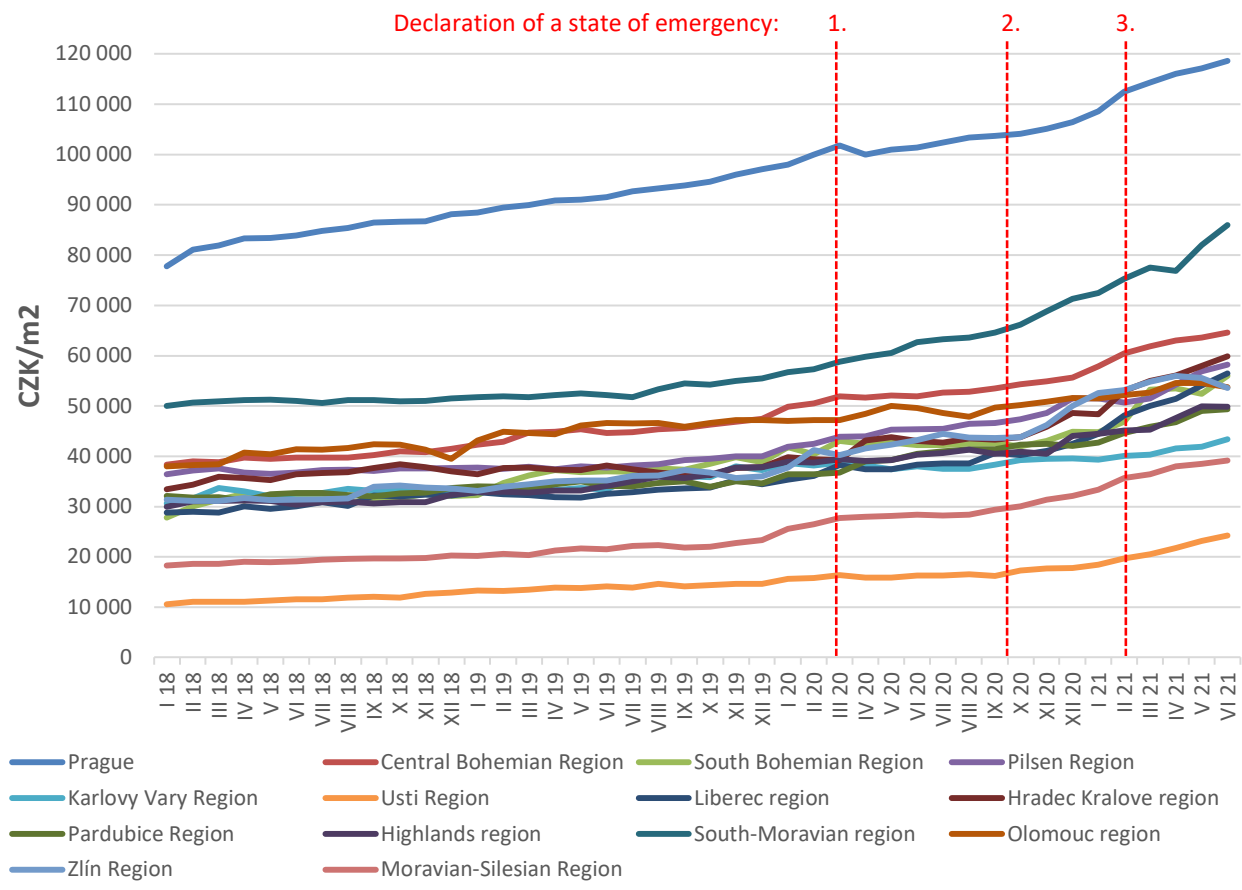

Fig. 1. Development of offer prices of flats intended for sale broken down by region (medians, price per $m^{2}$ of the floor area of a flat, time period 2018 to June 2021, older and new flats) 


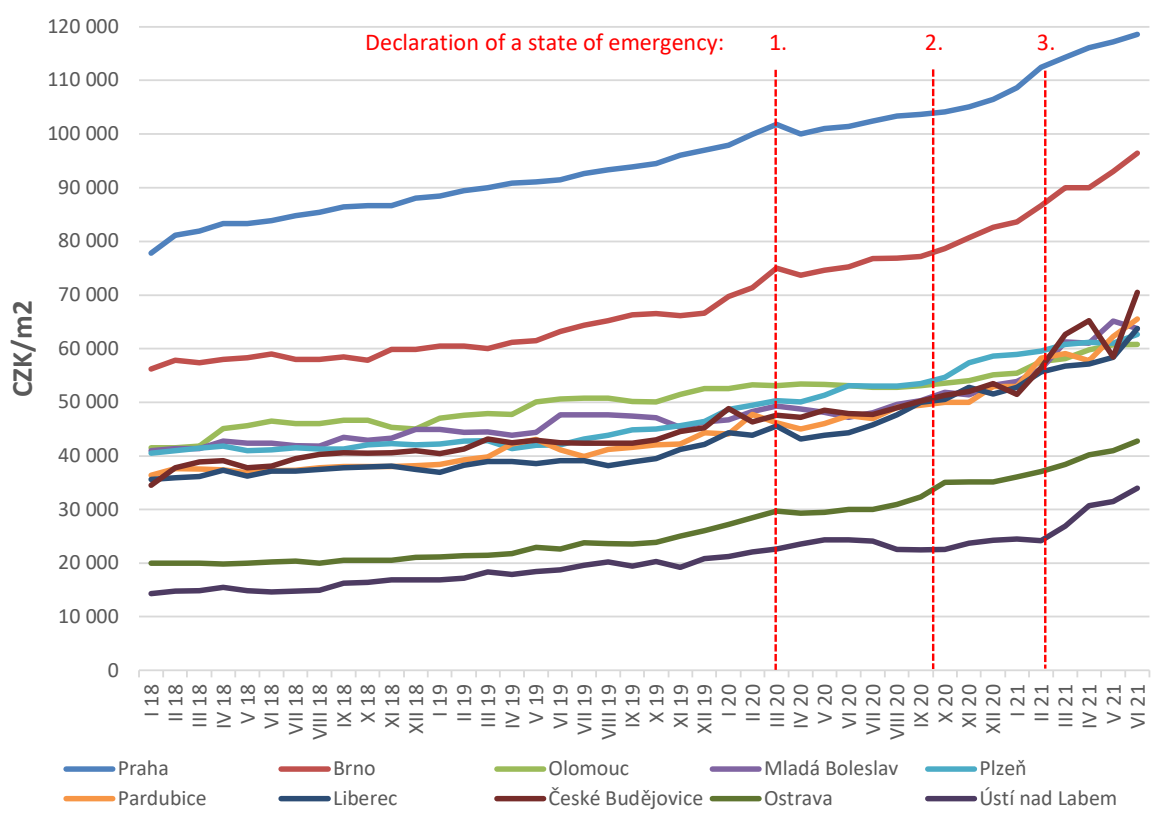

Fig. 2. Development of offer prices of flats intended for sale broken down by selected large cities (medians, price per $m^{2}$ of floor area of a flat, time period 2018 to June 2021, older and new flats)

The significant increase in the price level of offer prices of flats in recent years, which is shown in the previous graphs, is caused by a number of factors. These are mainly the following factors:

\section{A/ Low interest rates on mortgage loans:}

The following graph shows the development of the average interest rate on mortgages from 2010 to 2021 (Fincentrum Hypoindex). The Hypoindex represents the weighted average interest rate at which new mortgage loans for individuals are provided in a given calendar month. The volumes of loans provided serve as weights. Input data for Hypoindex calculations are provided by the following banks: Air Bank, Česká spořitelna, ČSOB, Equa Bank, Moneta Money Bank, Hypoteční banka, Komerční banka, Raiffeisenbank, Sberbank CZ and UniCredit Bank (Fincentrum Hypoindex, 2021).

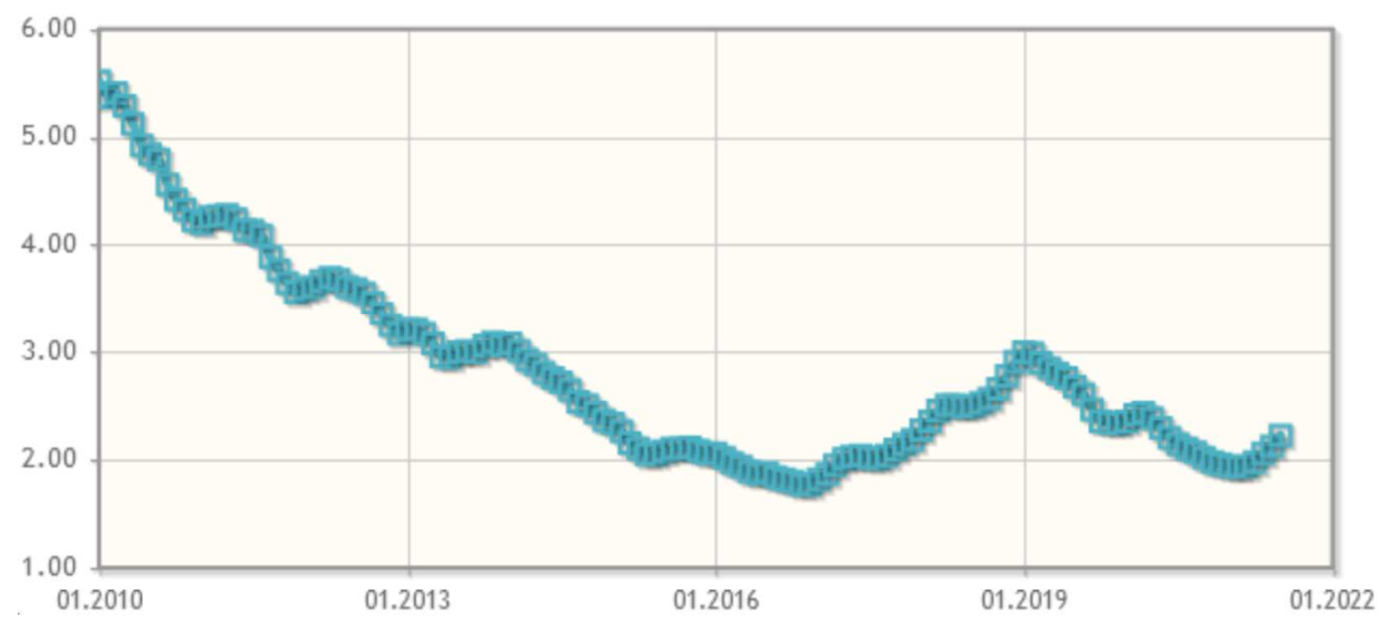

Fig. 3. Fincentrum Hypoindex - development - average mortgage interest rate Data source: Fincentrum Hypoindex, https://www.hypoindex.cz/hypoindex-vyvoj/, 2021

The above graph shows that average interest rates on mortgage loans are currently very low. The very low level of interest rates makes mortgages more affordable for households and individuals. This fact brings both positive and negative phenomena to society.

Many people and households try to take advantage of this advantageous situation and go to the real estate market in order to acquire real estate. Low levels of interest rates on mortgage loans are combined with very loose 
restrictions imposed by the regulator. Volumes of mortgages peaked in 2020, reflecting an unprecedented increase in demand on the housing property market. The overall sentiment on the Czech property market indicates that mortgages may soon be more expensive and less available. In 2020, for example, people in high-risk sectors most affected by the effects of the COVID-19 pandemic (gastronomy, hospitality, tourism, arts) tried to quickly obtain a mortgage until banks saw them as risky clients. If the bank had already indicated in advance its reluctance to provide a loan to these persons, it was more advantageous to withdraw from the mortgage application voluntarily, as otherwise, a record would appear in the credit register stating that this person was rejected by the bank when applying for the loan. Banks then consider this information relevant for further possible loan applications.

Recently, low interest rates are accompanied by increased savings in the hands of the Czech households and an inflation rate substantially exceeding expectations. These factors stand behind the remarkable demand-pull increase in acquisition prices of real estate. As prices increase, mortgage applicants can get into trouble in another area. The loan applicant must cover part of the value of the property from its own resources (need to respect the central bank's recommendations in terms of LTV). The LTV calculation is not based on the property's purchase price but on an estimate of the property's market value. These two values are not identical. The estimate is processed by the bank itself, or it is processed by an internal/external appraiser authorized by the bank.

At the same time, the growth in the total price of real estate increases the requirements for the loan applicant's own resources. Thus, paradoxically, low interest rates can, in some cases, limit the availability of owner-occupied housing. An interesting question to consider is what would happen to the real estate market and real estate prices if the Czech Republic paid in euros (link to interest rates of the European Central Bank, not link to interest rates of the Czech National Bank as before).

At present, there is still a paradox on the market. The average mortgage rate in May 2021 was $2.06 \%$ (Fincentrum Hypoindex, 2021), while the inflation rate in May 2021 was 2.8\% year-on-year (Czech Statistical Office, 2021). This leads to a strange phenomenon where the inflation rate is higher than the average interest rate on a mortgage, so borrowing at a subinflationary price of money is possible. This situation cannot be considered a normal and long-term sustainable economic environment. Thus, central banks indirectly create specific market imbalances in an effort to save individual economies.

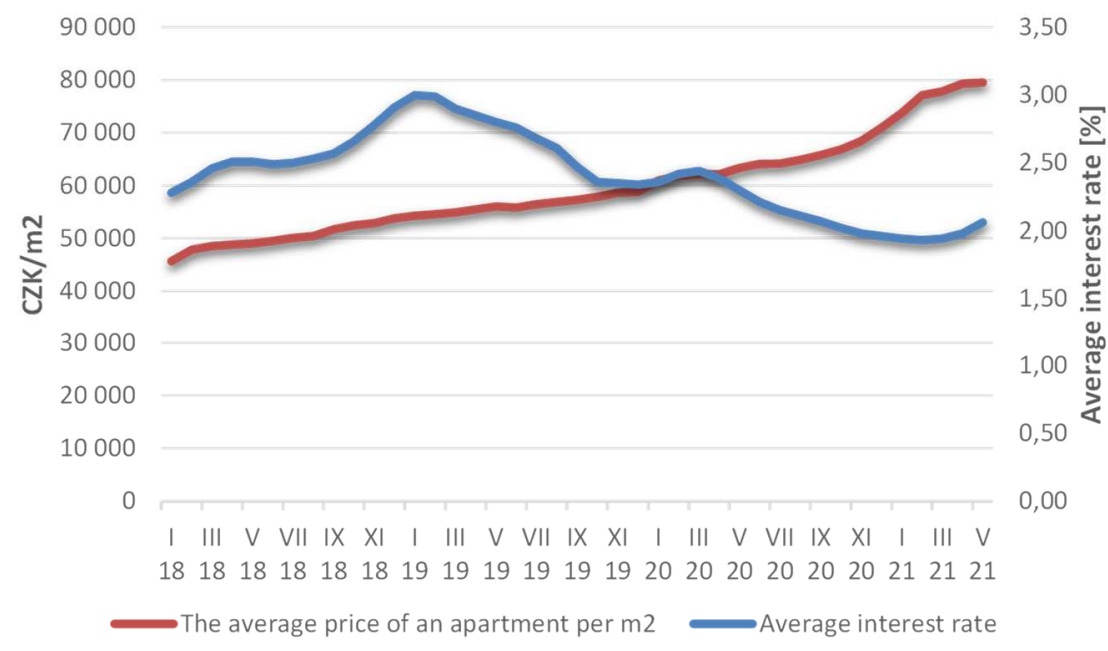

Fig. 4. Comparison of the average offer price per $m 2$ of the floor area of an apartment for sale and the average mortgage interest rate (averages, the whole Czech Republic, time period 2018 to May 2021, older and new apartments)

Data source: software EVAL, Fincentrum Hypoindex, https://www.hypoindex.cz/hypoindex-vyvoj/, 2021

The reason for the increased interest in mortgage loans is the expectations of households and individuals regarding the growth of mortgage interest rates for the next period. This future outlook motivates clients to make faster decisions, choose a suitable property faster and thus secure financing with the lowest possible interest rate. In this sense, the Czech property market is experiencing a stock up on the demand side.

Hand in hand with the short-term rentals (Airbnb) boom starting around 2012, the Czech real estate market (Prague especially) has experienced a massive inflow of foreign investments. Even if this share of demand has been substantially reduced during the Covid pandemic, it has been more than offset by domestic subjects' demand.

\section{B/ Monetary policy of central banks:}

Central banks use interest rates as their main monetary policy tool. However, during the COVID-19 pandemic, this basic instrument lost its effectiveness as interest rates approached or reached zero or negative levels. Central banks thus had to use other tools to loosen monetary policy. In particular, the so-called quantitative easing was used. In essence, it is the purchase of securities by a central bank in the financial market (Czech National 
Bank, 2021). This increases the amount of money in the economy and, at the same time, increases the prices of purchased assets. Interest rates are proving to be an important tool for central banks (Inhoffen et al., 2021).

A side effect of this phenomenon is that investors, savers, households, companies and, in fact, all economically active persons are increasingly concerned about inflation, which this loose monetary policy indirectly but significantly supports. As a side effect, central banks are increasing the demand for real estate through this policy.

Another side effect of this monetary policy of central banks is the fact that companies that would not have a chance to survive in the normal market environment survive on the market. We call such companies zombie companies (Favara et al., 2021). These are companies that only survived by unusually cheap financing. Zombie companies block many employees in virtual jobs, and viable and innovative companies find it difficult to find employees (Helmersson et al., 2021). This fact also significantly affects the construction sector, which has difficulty finding employees in all positions resulting in limited construction and limited housing construction. Thus, this impact is transferred to the size of supply and prices.

\section{C/ Resignation to pension reform:}

In particular, persons born in the 1980s and 1990s do not expect the state to offer them an adequate amount of pension at retirement age. Therefore, many of these people have taken the initiative into their own hands and are looking for safe ways to secure themselves in old age. Real estate thus began to replace the non-existent pension reform. Real estate is still perceived by society as a store of value even in times of crisis. Real estate is a conservative investment that also generates a stable return in the form of monthly rent. At the same time, due to the development of the real estate market and the policy of central banks, there is a significant increase in the residual value of the real estate. Even if the property is not rented, it serves as a store of value. However, this approach impairs the availability of real estate for people who really want to use the property for their own home and not as an investment.

\section{D/ Change of business strategy of development and construction companies:}

Another important factor that will reduce the availability of owner-occupied housing for households in the near future is the policy of developers and construction companies for the next period. It is possible to trace many interviews with owners and managers of development and construction companies (especially in 2020 and 2021) (for example, Hospodářské noviny, 2020, Forbes, 2021, E15, 2021), where they outline their future strategic behaviour. Until now, development companies usually functioned by building an apartment building, which they then sold immediately, generated a profit and then started further construction activities.

However, this well-established business model is currently changing. The development companies plan to keep part of the housing stock, which they will create in their ownership, and they will continue to rent these apartments themselves or with the use of an intermediary. Furthermore, construction and development companies plan to focus significantly more on institutional investors. The current business model - the sale of apartments mainly to individuals (natural persons) will be limited.

Institutional investors include, for example, pension and real estate funds, as well as any larger companies operating in any segment that want to place part of their capital in residential real estate. Until now, institutional investors have mostly avoided investing in residential real estate. They focused much more on commercial real estate - offices, warehouses and production halls. At present, however, it is difficult to find any profitable investment on the market, so that even residential properties, although providing lower returns, are becoming an interesting alternative.

Construction for an institutional investor has several advantages for developers and construction companies. On the one hand, they know their customer in advance, so they can precisely adapt the construction to his needs. Furthermore, easier financing of the project will be ensured because the institutional investor will certainly represent a very creditworthy client. The developer also does not have to deal with the lengthy sale of apartments to individuals because he will sell the residential property in one business transaction.

However, this fact will limit the supply of apartments for sale to individuals. Thus, significantly fewer flats will be released for free sale than they have been so far, even if construction production in the residential segment is maintained. The law of supply and demand will then cause an increase in residential property prices.

A key feature of the Czech property market during the last decade has been a sluggish supply. We have argued above that construction companies have limited capacity caused one by labour shortage (dramatically increased during the Covid pandemic) and two by strict building law. Very slow evaluation and building permission process increases transaction costs and make the real estate supply less elastic. In case of a demand increase on such a specific market, prices skyrocket.

Using regression analysis, the dependence of the number of months needed to save the amount for the acquisition of an apartment on the offer price of the apartment for sale is examined. The calculation assumes the acquisition of an average apartment with a floor area of $50 \mathrm{~m}^{2}$, which will require an additional initial investment 
of CZK 350,000. The average gross wage for a given region is included in the calculation. It is also assumed that the investor will defer from his salary the entire amount of payment for the acquisition of an apartment. This amount will be deposited in a noninterest bearing account. It is based on the median unit offer prices for the sale of flats for individual districts from the EVAL software for the period from January to June 2021.

We estimate the parameters of the regression function $y(x)=\alpha+\beta x$, which characterizes the relationship between the offer price of an apartment for sale and the number of months needed to save the amount for the acquisition of an apartment. Estimates of $a, b$ parameters $\alpha, \beta$ are performed by the least-squares method:

$$
\begin{aligned}
& b=\frac{n \sum_{i=1}^{n} x_{i} y_{i}-\sum_{i=1}^{n} x_{i} \sum_{i=1}^{n} y_{i}}{n \sum_{i=1}^{n} x_{i}^{2}-\left(\sum_{i=1}^{n} x_{i}\right)^{2}}=\frac{77 * 412246273-3651255 * 7956}{77 * 194896055813-3651255^{2}}=0,001608 \\
& a=\frac{\sum_{i=1}^{n} y_{i}-b \sum_{i=1}^{n} x_{i}}{n}=\frac{7956-0,001608 * 3651255}{77}=27,0552
\end{aligned}
$$

Estimation of regression function: $\hat{y}=27,0552+0,001608 x$

The correlation coefficient: $r_{x y}=0,9703$

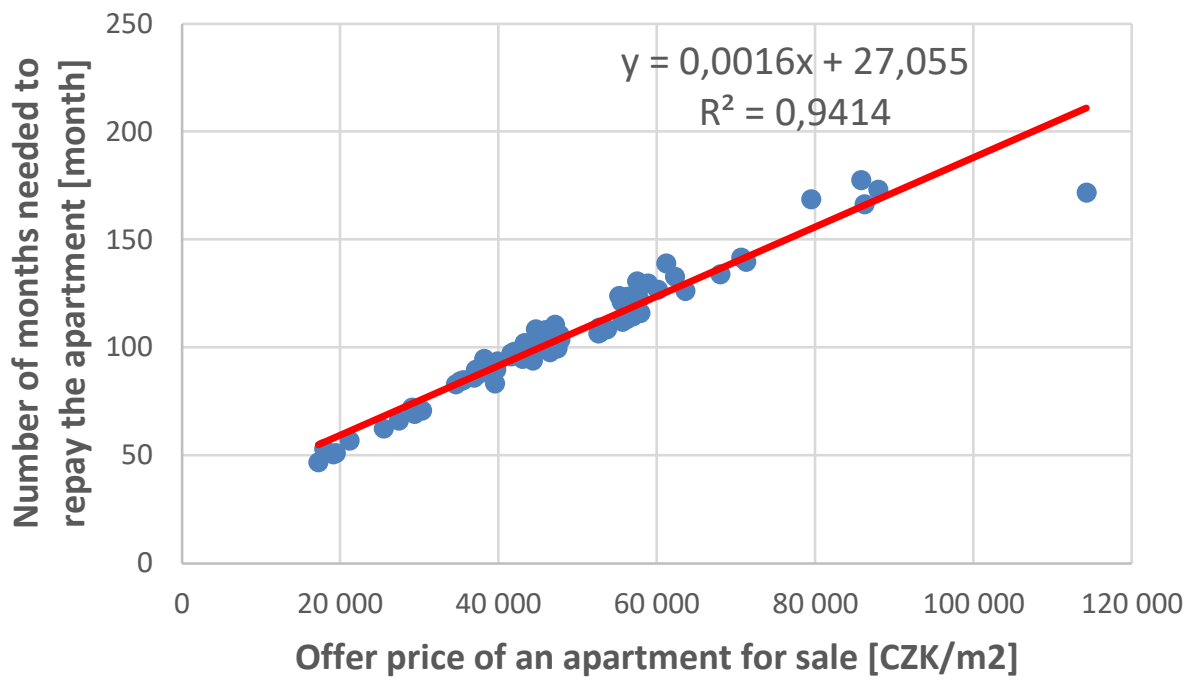

Fig. 5. Scatter plot of dependence and interpolated regression line-dependence of the number of months needed to save the amount for the purchase of an apartment with a floor area of $50 \mathrm{~m}^{2}$ on the median offer price of the apartment for sale (January to June 2021, older and new apartments, districts of the Czech Republic)

Data source: software EVAL, Ministry of Labor and Social Affairs of the Czech Republic, 2021

The dependence of the number of months needed to save the amount for the purchase of an apartment on the median offer price of the apartment for sale was observed. With the growth of the unit price of an apartment, the number of months of savings increases. In the scatter plot of the dependence, there are several values of the parameter $y$, which exceeded 160 months. These are the districts of Brno, Prague, Prague-West, Semily and Trutnov. The high price level in the Semily and Trutnov districts is due to the fact that there are many mountain apartments (luxury flats) in the price offers, for which there is very high demand during the COVID-19 pandemic. The regression analysis revealed that the unavailability of housing occurs mainly in the Czech Republic's large cities and tourist areas.

Furthermore, the dependence between the average amount of rent in individual regions of the Czech Republic and the average amount of wages was examined. In this case, only a low dependence was found. This is caused by the fact that the rental market is significantly influenced by the state's social policy (housing allowance, living allowance, immediate emergency assistance, other social benefits). There is an abuse of drawing social benefits by various groups of property owners and their tenants in specific localities of the Czech Republic and a distortion of the rental market. 


\section{Discussion}

Property market characteristics and housing affordability play a key role in determining labour mobility and structural unemployment. The relationship between labour mobility and housing has been investigated by many studies, i.e. Böheim (2002) or Gardner (2001).

The Czech Republic is a country with a very low level of cross-regional mobility (Huber 2005). The mobility is concentrated within each region. Missing cross-regional mobility embarrasses convergence between regions.

Lux et al. (2011) find out that willingness to move for a job in case of unemployment is substantially higher for tenants than for housing owners. One-third of owners were willing to move, but more than two-thirds of tenants. The data for the Czech Republic reveals a high share of housing owners (80\%) and, at the same time, a low level of cross-regional mobility. The data, therefore, seem to be in compliance with theoretical assumptions.

Another key feature of the Czech housing market is a high net income-to-rent ratio exceeding 50\%. Moving from a less developed region with lower wages to a region promising higher wages (and higher rents) is not affordable for many (also taking into consideration transaction costs of moving and deposit that is usually requested as backup provision for potential losses of the landlord. Lower-income workers resign to moving to regions with higher incomes, do not gain working experience and find it hard to cope with structural changes in the economy and often become unemployed. This vicious cycle is an obstacle to regional convergence and development. Low wages depress the purchasing power of households and limit new investments. Afflicted regions suffer from brain drain and depressed consumption.

What could be a policy recommendation? Currently, the government subsidizes rents for low-income tenants. This policy led to market deformations and rents increase. The subsidy ended up being rent for landowners. We argue that government support is needed, but the parameters of the support need to be changed. We propose introducing a system of convenient loans (not subsidies) for starting housing in a new locality or municipal flats available for short term subsidized rentals. The Czech Republic still has structurally disadvantaged regions with a high share of mining and heavy industry. Environmental aspects should also not be overlooked (Stefko et al., 2021). If workers remain locked in those regions due to high real estate prices and rents may be exposed to income poverty.

\section{Conclusions}

Our results show that differences in the availability of housing in individual regions of the Czech Republic are likely to increase in the future. We expect the biggest differences in the Prague region and in localities where there will be a reduction in the mining industry. We see an essential role of state policy in mitigating the negative effects of this phenomenon. The general role of the state is to ensure affordable, stable and sustainable housing. However, the policy should not be aimed at low-income groups only, nor should it subsidize home ownership, but rather it should be based on the approach that securing housing is a personal responsibility of each individual. The role of the state is to create a stable environment that supports the motivation of all participants in the housing market in their personal activities. At the same time, the state should use appropriate means to help those persons who, for objective reasons, are unable to provide housing themselves.

Our policy recommendation is concentrated on the supply side of the market. We argue that speeding up permitting processes and related infrastructure and amenities would be much more efficient than any measure focused on the demand side of the real estate market, which, as documented by several studies in various countries, leads to a further increase in property prices. We have discussed that both subsidies to low-income households or blanket incentives to buy own housing (such as tax reductions) will further increase property prices if the supply side is not able to keep up with housing demand.

It results necessary to support spatial planning activities and preparation of the territory for their further development. Territorial readiness and a mutually beneficial agreement for the private and public sectors are important.

We believe that instruments and measures supporting the construction of housing should differentiate between regions. Individual regions can be assessed not only with regard to the current intensity of construction but also with regard to the long-term need for housing, according to the current state of the population, according to the expected increase in population and the state of the housing stock.

The state should support housing cooperatives as an alternative to owner-occupied housing. Remove obstacles that prevent higher use of this form of support. The weak position of housing cooperatives in execution and insolvency is the main obstacle.

The state strategy of supporting the supply of rental housing and achieving an increase in the quality of rental housing may be very efficient in solving the vicious circle of housing unaffordability. Rental housing should become a common alternative to owner-occupied housing. Increasing the share of rental housing will contribute, among other things, to increasing the mobility of the population, increasing employment and increasing the income of the population. 
The Czech housing market has not undergone any recent property crash property crash. The specific structure of the Czech housing market influence how workers evaluate participation in the labour market, and we believe that the role of the government is very important. Our results indicate that government policy should be focused on supporting rentals in a new location as supporting homeownership could have an unintended lock-in effect.

\section{References}

Andrews, D., Sánchez, A. C., \& Johansson, Å. Housing Markets and Structural Policies in OECD Countries. OECD Economics Department Working Papers, No. 836, 2011. OECD Publishing, Paris. Retrieved from: doi: $10.1787 / 5 \mathrm{kgk} 8 \mathrm{t} 2 \mathrm{k} 9 \mathrm{vf} 3$-en

Bencsik, A., Juhacz, T., \& Mura, L. (2019). Consequences of Workplace Stress - Company Case Study. Littera Scripta, 12(2), 1-17.

Billionaire Skala developer. He wants to build apartments on the site of Koh-i-noor and Transgas [online]. Prague: Forbes, 2021 [cit. 2021-8-7]. Retrieved from: https://forbes.cz/psn-pri-chuti-skalovi-chystaji-noveakvizice-a-posouvaji-se-k-developmentu/

Böheim, R., \& Taylor, M. (2002). Tied down or room to move? Investigating the relationship between housing tenure, employment status and residential mobility in Britain. Scottish Journal of Political Economy.

Czech National Bank. (2021). Monetary policy at zero interest rates. Retrieved from: https://www.cnb.cz/en/menova-politika/vzdelavani/menova-politika-clanky/15-menova-politika-prinulovych-urokovych-sazbach/

Czech Statistical Office. (2021). Inflation - types, definitions, tables. Retrieved from: https://www.czso.cz/csu/czso/mira_inflace

Eurostat. (2021). Housing price statistics - house price index. Retrieved from: https://ec.europa.eu/eurostat/statistics-explained/index.php?title=Housing_price_statistics__house_price_index

E15. (2021). The Swedish Heimstaden bought a portfolio of rental apartments in Pilsen from the Israelis. Retrieved from: https://www.e15.cz/byznys/reality-a-stavebnictvi/svedsky-heimstaden-koupil-od-izraelcu-portfolionajemnich-bytu-v-plzni-1378855\#

Favara, G., Minoiu, C., \& Perez-Orive, A. U.S. Zombie Firms: How Many and How Consequential? FEDS Notes. Washington: Board of Governors of the Federal Reserve System. https://doi.org/10.17016/2380-7172.2954

Fincentrum Hypoindex, (2021]). Prague: Fincentrum Hypoindex, 2021. Retrieved from: https://www.hypoindex.cz/

Gardner J., Pierre, G., \& Oswald, A. (2001). Moving for job reasons. Working paper, University of Warwick

Gavurova, B., Belas, J., Zvarikova, K., Rigelsky, M., \& Ivankova, V. (2021a). The effect of education and R\&D on tourism spending in OECD countries: An empirical study. Amfiteatru Economic, 23(58), 806-823. https://doi.org/10.24818/EA/2021/58/806

Gavurova, B., Belas, J., Valaskova, K., Rigelsky, M., \& Ivankova, V. (2021b). Relations between infrastructure innovations and tourism spending in developed countries: A macroeconomic perspective. Technological and Economic Development of Economy, 27(5), 1072-1094. https://doi.org/10.3846/tede.2021.1536

Helmersson, T., Mingarelli, L., Mosk, B., Pietsch, A., Ravanetti, B., Shakir, T., \& Wendelborn, J. (2021) Corporate zombification: post-pandemic risks in the euro area. Financial Stability Review. European Central Bank. Retrieved from: stability/fsr/special/html/ecb.fsrart202105_01 f9b060744e.en.html

Heralova Schneiderova, R. (2017). Life Cycle Costing as an Important Contribution to Feasibility Study in Construction Projects. Procedia Engineering, 196, 565-570. https://doi.org/10.1016/j.proeng.2017.08.031

Hrmo, R., Kristofiakova, L., \& Barnova, S. (2020). Internal System of Quality Management in the Context of Ensuring the Quality of Preparation of Managers for Future Practice. Littera Scripta, 13(2), 70-81.

Huber, P. (2005). Interregional mobility in the accession countries: a comparison of EU-15 Member States. Working paper No. 249, WIFO.

Hyötyläinen, M., \& Haila, A. (2018). Entrepreneurial public real estate policy: The case of Eiranranta, Helsinki. Geoforum, 89, 137-144 https://doi.org/10.1016/j.geoforum.2017.04.001

Inhoffen, J., Pekanov, A., \& Url, T. (2021). Low for Long: Side Effects of Negative Interest Rates. Publication for the committee on Economic and Monetary Affairs, Policy Department for Economic, Scientific and Quality of Life Policies, European Parliament, Luxembourg. Retrieved from: https://www.europarl.europa.eu/cmsdata/235693/02.DIW_formatted.pdf

Jašová, E., Čermáková, K., Kadeřábková, B., \& Procházka P. (2016) Influence of Institutional Factors on Structural and Cyclical Un-employment in the Countries of the Visegrad Group. Politická Ekonomie. 64(1), 34-50. https://doi.org/10.18267/j.polek.1053) 
Kadeřábková, B., \& Jašová E. (2019). Development of real unit wage costs on the macro- and mezo- level of the Czech Republic. International Journal of Economic Sciences, 8(2), 45-59.

Kadeřábková, B., \& Lukavec, M. (2017). How much does a minute of commuting time cost? An examination of property prices in relation to distance to the city center in Prague, Czech Republic. The Civil Engineering Journal, 26(4), 555-567.

Kliestik, T., Misankova, M., Valaskova, K., \& Svabova, L. (2018). Bankruptcy Prevention: New Effort to Reflect on Legal and Social Changes. Science and Engineering Ethics, 24(2), 791-803. https://doi.org/10.1007/s11948-017-9912-4

Kowalik, Z. (2020). Policies to ensure access to affordable housing. Directorate-General for Internal Policies, European Parliament. ISBN 978-92-846-6950-9

Krapf, S., \& Wagner, M. (2021). Correction to: Housing Affordability, Housing Tenure Status and Household Density. European Journal of Population. https://doi.org/10.1007/s10680-021-09587-z

Krulický, T., Vrbka, J., \& Brabenec, T. (2020). Determining the amount of past investment property using the synthesis of cost evaluation methods. IOP Conference Series: Materials Science and Engineering. https://doi.org/10.1088/1757-899X/960/4/042102

Le Goix, R., Ysebaert, R., \& Timothée G. (2021). Unequal housing affordability across European cities. The ESPON Housing Database, Insights on Affordability in Selected Cities in Europe. Cybergeo. https://doi.org/10.4000/cybergeo.36478

Leung, C. K, Y., Ng J. C. Y., \& Tang, E. C. H. (2020). Why is the Hong Kong Housing Market Unaffordable? Some Stylized Facts and Estimations. Federal Reserve Bank of Dallas, Globalization Institute Working Papers. https://doi.org/10.24149/gwp380

Lux, M., \& Sunega, P. (2012). Labour Mobility and Housing. Urban Studies, 49(3), 489-504. https://doi.org/10.1177/0042098011405693

Macek, D. (2010). Building maintenance and renovation. In: Central Europe towards Sustainable Building. Hájek, P., eds. Prague: Czech Technical University, p. 669-672.

Ministry of Labor and Social Affairs of the Czech Republic. (2021). Regional labor cost statistics. Retrieved from: https://www.mpsv.cz/statistika-vydelku

Novak, V. (2017). The Spatial Delimitation of Agglomerations in the Czech Republic: The Case of Northwestern Bohemia. Littera Scripta, 10(2).

Novak, V., Vokoun, M., Stellner, F., \& Vochozka, M. (2016). Institutional analysis of the contemporary regional labour market in the Czech Republic. $E$ \& $M$ Ekonomie a Management, 19(3), 4-19. https://doi.org/10.15240/tul/001/2016-3-001

Novotna, M., Volek, T., Rost, M., \& Vrchota, J. (2021). Impact of technology investment on firm's production efficiency factor in manufacturing. Journal of Business Economics and Management, 22, 135-155. https://doi.org/10.3846/jbem.2020.13635

Ronald, R. (2020). Transformations in housing and housing policy research: plus ça change, plus c'est la même chose. International Journal of Housing Policy, 20(1), 1-5. https://doi.org/10.1080/19491247.2019.1706889

Roulac, S. (1996). Real Estate Market Cycles, Transformation Forces and Structural Change. Journal of Real Estate Portfolio Management, 2(1), 1-17. https://doi.org/10.1080/10835547.1996.12089519

Shi, L., Sheng, P. F., \& Vochozka, M. (2017). The reduction cost of nonperforming loan: evidence from China's commercial bank. Applied Economics Letters, 24(7), 456-459. https://doi.org/10.1080/13504851.2016.1203052

Stefko, R., Gavurova, B., Kelemen, M., Rigelsky, M., \& Ivankova, V. (2021). Relationships between renewable energy and the prevalence of morbidity in the countries of the European Union: A panel regression approach. International Journal of Environmental Research and Public Health, 18 (12), 6548. https://doi.org/10.3390/ijerph18126548

Hospodářské noviny. (2020). The time has come to build rental apartments. Rents will be stable in Prague, says the developer. Retrieved from: https://archiv.hn.cz/c1-66790270-nadesel-cas-vystavby-najemnich-bytu-vpraze-budou-najmy-stabilni-rika-developer

Urban, D., \& Kajanova, A. (2020). Financial and Informational Social Support for the Residents of the České Budějovice Region. Littera Scripta, 13(2), 39-48.

Vochozka, M., Vrbka, J., \& Suler, P. (2020). Bankruptcy or Success? The Effective Prediction of a Company's Financial Development Using LSTM. Sustainability, 12(18), 7529. https://doi.org/10.3390/su12187529

Volek, T., \& Novotna, M. (2015). Gross Value Added and Total Factor Productivity in Czech Sectors. Contemporary Economics, 9, 17-27. https://doi.org/10.5709/ce.1897-9254.157

Vrbka, J., Krulicky, T., Brabenec, T., \& Hejda, J. (2020). Determining the Increase in a Building's Appreciation Rate Due to a Reconstruction. Sustainability, 12(18), 7690. https://doi.org/10.3390/su12187690

Zhang, B. (2020). Social policies, financial markets and the multi-scalar governance of affordable housing in Toronto. Urban Studies, 57(13), 2628-2645. https://doi.org/10.1177/0042098019881368 